\title{
Bibliometric Analysis of Publications from Web of Science Affiliated to Health Sciences University from 2017-2019
}

\author{
Roshan Umate ${ }^{1}$, Manoj Patil ${ }^{2}$, Shital Telrandhe ${ }^{3}$, Aniket Pathade ${ }^{4}$ \\ ${ }^{1}$ Department of Research and Development, Jawaharlal Nehru Medical College, Datta Meghe Institute of \\ Medical Sciences, Wardha, Maharashtra, India. ${ }^{2}$ Department of Research and Development, Jawaharlal \\ Nehru Medical College, Datta Meghe Institute of Medical Sciences, Wardha, Maharashtra, India. \\ ${ }^{3}$ Department of Research and Development, Jawaharlal Nehru Medical College, Datta Meghe Institute of \\ Medical Sciences, Wardha, Maharashtra, India. ${ }^{4}$ Department of Research and Development, Jawaharlal \\ Nehru Medical College, Datta Meghe Institute of Medical Sciences, Wardha, Maharashtra, India.
}

\section{ABSTRACT}

\section{BACKGROUND}

Bibliometrics is the use of statistical methods for analysing books, articles, and other publications. It is useful to analyse the research impact, assess the quality of research using quantitative and qualitative measures, describe patterns of publication, determine the influence of writers, describe the relationship between different writers or researches. This study was conducted to evalute the number and trends of materials affiliated to Health Sciences University published in Web of Science indexed journals.

\section{METHODS}

This was a retrospective observational study. The Web of Science database was accessed through institutional Login and all published materials affiliated to Health Sciences University were searched. The file of all searched materials was exported in BibTex format, which was fed to R-Studio Application after installing the Bibliometrics package. Imported data was downloaded and bibliographic data frame was created. Basic information of publications was recorded including the number of citations, citation density, journals, publication year, authors, institution and country of origin. Results were summarized using descriptive statistics.

\section{RESULTS}

Bibliometric analysis of publications affiliated to Health Sciences University between 2017 to 2019 generated a list of 182 articles from 75 sources which included 180 Journal Articles and 2 articles in Book Chapters. Highest number of publications were 82 in the year 2019 followed by 51 in 2017 and 49 in 2018. The Annual Percentage Growth Rate of Scientific Productions was 26.8. The publications showed total 2170 authors of which 09 were authors of 'single-authored documents' and 2163 were authors of 'multi-authored documents'. The Collaboration Index of all published materials was 12.5 .

\section{CONCLUSIONS}

This analysis reflects on the historical perspectives of Health Sciences University publications and its progress in Web of Science indexed Scientific Medical Literature database.

\section{KEY WORDS}

Bibliography, R-Studio, Health Sciences University, Web of Science, Publications, Indexing

\begin{abstract}
Corresponding Author: Dr. Manoj Patil,

Department of Research and Development, School of Epidemiology and Public Health, Datta Meghe Institute of Medical Sciences, Sawangi (M), Wardha. Maharashtra, India.

E-mail:mpatil98dent@gmail.com
\end{abstract}

DOI: $10.14260 /$ jemds/2020/386

Financial or Other Competing Interests: None.

How to Cite This Article:

Umate $R$, Patil $M$, Telrandhe $S$, et al. Bibliometric Analysis of Publications from Web of Science affiliated to Health Sciences University from 2017-2019

J. Evolution Med. Dent. Sci. 2020;9(23): 1756-1764, DOI:
Submission 28-03-2020,

Peer Review 14-05-2020,

Acceptance 20-05-2020,

Published 08-06-2020. 


\section{BACKGROUND}

Bibliometrics is the use of statistical methods for analysing books, articles, and other publications, frequently used for library and information sciences.(1) It analyses the impact of research outputs using quantitative measures, complements qualitative research indicators and assists in assessing the quality and impact of research.(2-4) Quantitative analysis and statistics are helpful to describe publication patterns, determine the influence of writers, analyses the relationships between different writers or researchers and their researches. Indexation of journals is another key issue reflecting quality of published materials. Web of Science is among the world's best citation databases which is publisher-independent and trusted globally. ${ }^{(5)}$ Web of Science is the key base scaffold for most of the bibliometric studies conducted till date.(2) As per the Journal Citation Reports (JCR)- 2019, the ISI Web of Science has indexed 11877 journals from about 81 countries.(6) This study was conducted to see the number and trends of materials affiliated to Health Sciences University published in Web of Science indexed journals.

\section{METHODS}

This was a retrospective observational study. On March 24, 2020 , the ISI Web of Science database was accessed to gather academic publications of Sciences university in Central India from 2017 to 2019. All publications affiliated to Health Sciences University were searched from the ISI Web of Science Core Collection database (SCI-E and SSCI) using the Specific search terms using organization enhanced [OG] with the name of the Health Sciences university in Central India. In the "document type" field, search filter was set for articles only (excluding the other document types such as reviews and meeting abstracts), with English as the language of writing and publication for the period from 2017 until the end of 2019. Key bibliometric information was retrieved later which included author names and author affiliations, journal names, title of publication, year of publication, document type, etc.

Bibliometric analysis was performed with quantitative analysis approach and knowledge mapping technique. Information on Web of Science was used for running the quantitative analysis whereas for Knowledge mapping (network analysis) R Studio and BibExcel was used. It focused on the network and "link strength" between author keywords, countries, institutions, and authors. Fractional counting was performed to generate co-occurrence and co-authorship network outputs for most frequently used author keywords, network of top countries, network of top institutions and network of most productive authors.

\section{RESULTS}

The Web of Science search filtered for 'Document TypeArticles' affiliated to Health Sciences University generated a list of 182 articles from 75 sources over a period of 2017 to 2019. These included articles from different research areas such as -

1. Anatomy \& Morphology $(7)-1$

2. Cardiovascular System(8-14)-7

3. Dentistry \& Oral Medicine(15-40) -26

4. Dermatology(41) -1

5. Endocrinology \& Metabolism(42-43)-2

6. Environmental Sciences \& Ecology(44) -1

7. Gastroenterology \& Hepatology(45)-1

8. General Internal Medicine ${ }^{(46-121)}-76$

9. Geriatrics Gerontology (122-123)-2

10. Health Care Science Services(124-127) - 4

11. Infectious Diseases (128-129)- 2

12. Integrative Complementary Medicine (130-131)-2

13. Neurosciences \& Neurology(132) -1

14. Oncology(133-136) - 4

15. Otorhinolaryngology (137)-1

16. Pathology (138-144)- 7

17. Pediatrics (145-148)-4

18. Psychiatry(149-153) -5

19. Public Environmental Occupational Health(154-161)-8

20. Radiology, Nuclear Medicine Medical Imaging(162)- 1

21. Research Experimental Medicine(163-175)- 13

22. Respiratory System (176)-1

23. Surgery (177-180)-4

24. Urology Nephrology (181-188)-8

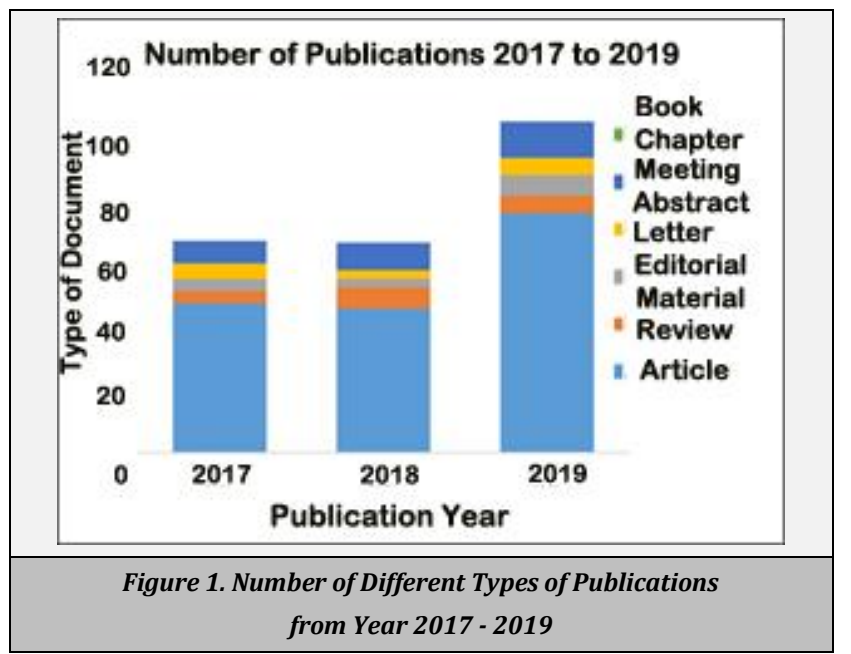

Highest number of publications were 82 in the year 2019 followed by 51 in 2017 and 49 in 2018. The Annual Percentage Growth Rate of Scientific Productions was 26.8. The publications showed total 2170 authors of which 09 were authors of 'single-authored documents' and 2163 were authors of 'multi-authored documents'. The Collaboration Index of all published materials was 12.5. Corresponding Authors for 165 articles belonged to India and 16 articles belonged to other countries including 4 from UK, 4 from USA, 2 each from Australia and New Zealand and 1 each from Netherlands, Saudi Arabia, Canada and France. Grand total of Sum of Total Citations was 592 among which highest was 384 in the year 2018 followed by 120 in 2019 and 88 in 2017. 

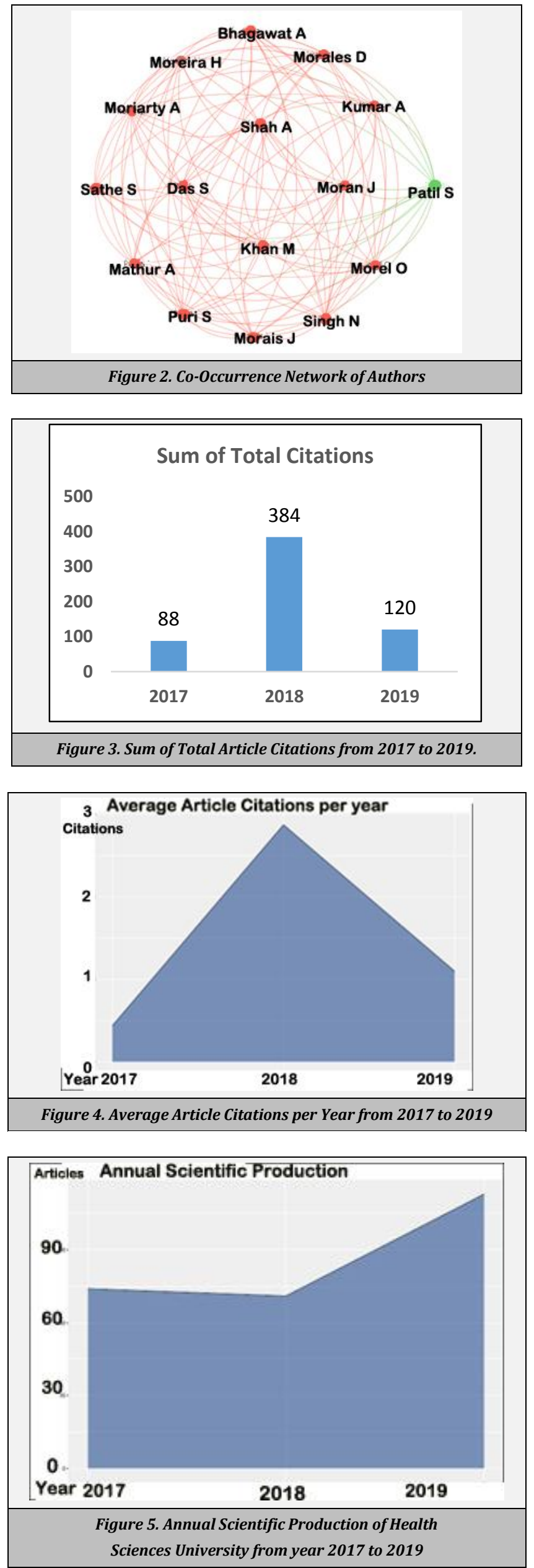

\section{DISCUSSION}

The published materials of Health Sciences University show an increase in the year 2019 whereas the sum of total citations of published materials show a prominent rise in the year 2018. The sum of total citations of materials published in 2019 is expected to show sharp rise in the year 2020. For the 182 articles published from 2017 to 2019, average Citations per item was 3.25 .

From the list of 2170 authors, the most productive author has 25 articles to his credit. The list of most relevant sources included Journal of Clinical and Diagnostic Research (29 articles), Journal of Evolution of Medical And Dental Sciences (28 articles), International Journal of Ayurvedic Medicine (10 articles), Journal Of Krishna Institute Of Medical Sciences University (9 articles), Saudi Journal Of Kidney Diseases And Transplantation (7 articles), Contemporary Clinical Dentistry(4 articles), Acta Cytologica (3 articles), Archives Of Psychiatry And Psychotherapy (3 articles), BMC Public Health (3 articles), Journal of International Society of Preventive And Community Dentistry ( 3 articles).

The trend of Health Sciences University authored publications in esteemed Web of Science indexed journals is improving and number of collaborative publications with citations are expected to improve over the following years.

\section{CONCLUSIONS}

This analysis reflects on the historical perspectives of Health Sciences University publications and its progress of scientific productions in Web of Science indexed Scientific Medical Literature database. The Annual Percentage Growth Rate of Scientific Productions of Health Sciences University was 26.8, which is appreciable. Still there is a great scope to improve the Growth Rate of Scientific Productions and Collaboration Index of Health Sciences University Publications.

\section{REFERENCES}

[1] What is bibliometrics? Measuring research impact Library, University of Leeds. [cited 2020 Feb 22].

[2] Zhang X, Estoque RC, Xie H, et al. Bibliometric analysis of highly cited articles on ecosystem services. PLoS One 2019;14(2):e0210707.

[3] Jain S, Basavaraj P, Singla A, et al. Bibliometric Analysis of Journal of Clinical and Diagnostic Research (Dentistry Section; 2007-2014). J Clin Diagn Res 2015;9(4):ZC4751.

[4] Bibliometrics - Research Methodologies Guide - Library Guides at Iowa State University [cited 2020 Feb 22].

[5] Web of Science - Web of Science Group [cited 2020 Feb 22].

[6] Clarivate Analytics releases 2019 Journal Citation Reports. Editage Insights [cited 2020 Mar 24].

[7] Sthapak E, Gajbe U, Singh BR. Study of communication between musculocutaneous and median nerves in man. Journal of the Anatomical Society of India 
2018;67(2):S37-S44.

https://doi.org/10.1016/j.jasi.2018.05.005.

[8] Goodman SG, Aylward PE, Szarek M, et al. Effects of alirocumab on cardiovascular events after coronary bypass surgery. Journal of the American College of Cardiology 2019;74(9):1177-86.

[9] Jukema JW, Szarek M, Zijlstra LE, et al. Alirocumab in patients with polyvascular disease and recent acute coronary syndrome odyssey outcomes trial. Journal of The American College of Cardiology 2019;74(9):116776.

[10] Roe MT, Li QH, Bhatt DL, Bittner VA, et al. Risk categorization using new American College of Cardiology/American Heart Association Guidelines for cholesterol management and its relation to alirocumab treatment following acute coronary syndromes. Circulation 2019;140(19):1578-89.

[11] Steg PG, Szarek M, Bhatt DL, et al. Effect of alirocumab on mortality after acute coronary syndromes. Circulation 2019;140(2):103-12.

[12] Szarek M, Ph. Steg G, DiCenso D, et al. Alirocumab reduces total hospitalizations and increases days alive and out of hospital in the ODYSSEY OUTCOMES trial. Circulation Cardiovascular Quality and Outcomes 2019;12(11):e005858.

[13] Szarek M, White HD, Schwartz GG, et al. Alirocumab reduces total nonfatal cardiovascular and fatal events the ODYSSEY OUTCOMES trial. Journal of The American College of Cardiology 2019;73(4):387-96.

[14] White HD, Ph. Steg G, Szarek M, et al. Effects of alirocumab on types of myocardial infarction: insights from the ODYSSEY OUTCOMES trial. European Heart Journal 2019;40(33):2801-9.

[15] Agarwal A, Bhola N, Kambala R, et al. Touch imprint cytology: can it serve as an alternative to frozen section in intraoperative assessment of cervical metastasis in oral squamous cell carcinoma? Journal of Oral And Maxillofacial Surgery 2019;77(5):994-9.

[16] Bhola N, Jadhav A, Kala A, et al. Anterior submandibular approach for transmylohyoid endotracheal intubation: a reappraisal with prospective study in 206 cases of craniomaxillofacial fractures. Craniomaxillofacial Trauma \& Reconstruction 2017;10(4):255-62.

[17] Chandak LG, Lohe VK, Bhowate RR, et al. Correlation of mandibular radiomorphometric indices with serum calcium and serum estradiol in pre- and postmenopausal women. Contemporary Clinical Dentistry 2017;8(1):53-8.

[18] Dhote VS, Thosar NR, Baliga SM, et al. Surgical management of large radicular cyst associated with mandibular deciduous molar using platelet-rich fibrin augmentation: a rare case report. Contemporary Clinical Dentistry 2017;8(4):647-9.

[19] Gadbail AR, Chaudhary MS, Sarode SC, et al. Ki67, CD105 and alpha-smooth muscle actin expression in disease progression model of oral sub mucous fibrosis. Journal of Investigative and Clinical Dentistry 2019;10(4):e12443.

[20] Gadbail AR, Chaudhary M, Gawande M, et al. Oral squamous cell carcinoma in the background of oral submucous fibrosis is a distinct clinicopathological entity with better prognosis. Journal of Oral Pathology \& Medicine 2017;46(6):448-53.
[21] Gadbail AR, Chaudhary M, Sarode SC, et al. Ki67, CD105 and Alpha-SMA expressions better relate the binary oral epithelial dysplasia grading system of World Health Organization. Journal of Oral Pathology \& Medicine 2017;46(10):921-7.

[22] Gondivkar SM, Bhowate RR, Gadbail AR, et al. Impact of oral sub mucous fibrosis on oral health-related quality of life: a condition-specific OHRQoL-OSF instrument analysis. Oral Diseases 2018;24(8):1442-8.

[23] Hotwani K, Sharma K. Assessment of the Impact of colors on child's anxiety and treatment preference for local anesthesia injections. Journal of Advanced Oral Research 2017;8(1\&2):42-6.

[24] Jadhav VD, Motwani BK, Shinde J, et al. Comparative evaluation of conventional and accelerated castings on marginal fit and surface roughness. Contemporary Clinical Dentistry 2017;8(3):405-10.

[25] Jain A. Accidental displacement of mandibular first molar root into buccal space: a unique case. Journal of Stomatology Oral and Maxillofacial Surgery 2018;119(5):429-31.

[26] Karia H, Shrivastav S, Karia AK. Three-dimensional evaluation of the airway spaces in patients with and without cleft lip and palate: a digital volume tomographic study. American Journal of Orthodontics and Dentofacial Orthopedics 2017;152(3):371-81.

[27] Khasbage SD, Bhake AS. Cervical lymphadenopathy in a dental patient: an eye opener case report. Special Care in Dentistry 2019;39(1):59-64.

[28] Nimonkar SV, Belkhode VM, Godbole SR, et al. Comparative evaluation of the effect of chemical disinfectants and ultraviolet disinfection on dimensional stability of the polyvinyl siloxane impressions. Journal of International Society of Preventive and Community Dentistry 2019;9(2):152-8.

[29] Oswal S, Borle R, Bhola N, et al. Surgical staples: a superior alternative to sutures for skin closure after neck dissection-a single-blinded prospective randomized clinical study. Journal of Oral and Maxillofacial Surgery 2017;75(12):2707.e1-e6.

[30] Panchbhai A. Effect of oral submucous fibrosis on jaw dimensions. Turkish Journal of Orthodontics 2019;32(2):105-9.

[31] Panchbhai A. Nanocomposites: past, present and future of dentistry. In: Asiri AM, Inamuddin, Mohammad A, eds. Applications of nanocomposite materials in dentistry. Woodhead Publishing Series in Biomaterials 2019: p. 181-90.

[32] Panchbhai A. Nanotechnology in Dentistry. In: Asiri AM, Inamuddin, Mohammad A, eds. Applications of nanocomposite materials in dentistry. Woodhead Publishing Series in Biomaterials 2019: p. 191-203.

[33] Parlani S, Tripathi S, Bhoyar A. A cross-sectional study to explore the reasons to visit a quack for prosthodontic solutions. Journal of Indian Prosthodontic Society 2018;18(3):231-8.

[34] Pisulkar SK, Agrawal R, Belkhode V, et al. Perception of buccal corridor space on smile aesthetics among specialty dentist and layperson. Journal of International Society of Preventive and Community Dentistry 2019;9(5):499-504.

[35] Prasad S, Ravindran S, Radhakrishnan V, et al. Initial experiences with NAM-assisted primary repair of the BCLP deformity. Special Care in Dentistry 2017;37(6):304-8

[36] Rathi NV, Chandak MG, Mude GA. Comparative evaluation of dentinal caries in restored cavity 
prepared by galvanic and sintered burs. Contemporary Clinical Dentistry 2018;9(Suppl 1):S23-S7.

[37] Reddy KV, Jadhav A, Bhola N, et al. Is $0.75 \%$ ropivacaine more efficacious than $2 \%$ lignocaine with 1:80,000 epinephrine for IANB in surgical extraction of impacted lower third molar? Oral and Maxillofacial Surgery 2019;23(2):225-31.

[38] Sarode SC, Chaudhary M, Gadbail A, et al. Dysplastic features relevant to malignant transformation in atrophic epithelium of oral submucous fibrosis: a preliminary study. Journal of Oral Pathology \& Medicine 2018;47(4):410-16.

[39] Sathe S, Karva S, Borle A, et al. Comparative evaluation of the effect of three polishing agents on staining characteristics of provisional restorative material: an in vitro study. Journal of International Society of Preventive and Community Dentistry 2019;9(3):250-5.

[40] Singh KD, Yunus N, Yanglem A. A study on the selection of maxillary anterior teeth size in Manipuri population. Annals of Dental Specialty 2018;6(4):393-6.

[41] Saoji V, Madke B. Use of low-dose oral warfarin in three cases of livedoid vasculopathy. Indian Journal of Dermatology 2017;62(5)508-11.

[42] Rathi N, Taksande B, Kumar S. Nerve conduction studies of peripheral motor and sensory nerves in the subjects with pre-diabetes. Journal of Endocrinology and Metabolism 2019;9(5):147-50.

[43] Ray KK, Colhoun HM, Szarek M, et al. Effects of alirocumab on cardiovascular and metabolic outcomes after acute coronary syndrome in patients with or without diabetes: a pre-specified analysis of the ODYSSEY OUTCOMES randomised controlled trial. Lancet Diabetes \& Endocrinology 2019;7(8):618-28.

[44] Regmi PR, van Teijlingen E, Mahato P, et al. The health of Nepali migrants in India: a qualitative study of lifestyles and risks. International Journal of Environmental Research and Public Health 2019;16(19):3655.

[45] Kirnake V, Arora A, Sharma P, et al. Non-invasive aspartate aminotransferase to platelet ratio index correlates well with invasive hepatic venous pressure gradient in cirrhosis. Indian Journal of Gastroenterology 2018;37(4):335-41.

[46] Acharya S, Sukla S, Rasheed, et al. Scrub typhus presenting as meningitis multiorgan dysfunction syndrome. Journal of Evolution of Medical and Dental Sciences - JEMDS 2019;8(43):3285-7.

[47] Acharya S, Samarth S, Anil W. Subclinical risk markers for Cardiovascular Disease (CVD) in Metabolically Healthy Obese (MHO) subjects. Journal of Clinical and Diagnostic Research 2019;13(6):OC01-0C06.

[48] Agrawal S, Sunil K, Vaibhao G, et al. Electrocardiography and echocardiography correlation in patients of left ventricular hypertrophy. Journal of Clinical and Diagnostic Research 2019;13(12):0C01OC04.

[49] Arora D, Yadav P, Harika V, et al. Anabolic-Androgenic Steroid (AAS) induced bowel ulcers mimicking inflammatory bowel disease in a young man. Journal of Evolution of Medical and Dental Sciences - JEMDS 2019;8(50):3816-8.

[50] Bains SK, John P, Nair D, et al. Aptitude of medical research in undergraduate students of a medical university - miles to go before we sow. Journal of Clinical and Diagnostic Research 2017;11(12):JC07JC11.

[51] Belkhode VM, Nimonkar SV, Agarwal A, et al. Prosthodontic rehabilitation of patient with mandibular resection using overlay prosthesis: a case report. Journal of Clinical and Diagnostic Research 2019;13(2):ZD10-ZD13.

[52] Bhat N, Mantri SS., Iliev GV, et al. First impression of teeth design on others: a facial and personality analysis in the central Indian population. Nigerian Journal of Clinical Practice 2019;22(11):1503-8.

[53] Avni B, Bhagwat A, Acharya S, et al. Postpartum Haemolytic Uremic Syndrome (PHUS) with Posterior Reversible Encephalopathy Syndrome (PRES) complicating pregnancy: a rare case report. Journal of Clinical and Diagnostic Research 2019;13(4):OD1-OD3.

[54] Nameirakpam C, Chaudhary M, Sonkusale M, et al. A prospective study of intraoperative comparison between general anaesthesia with conventional opioid and thoracic epidural anaesthesia for off pump coronary artery bypass surgery. Journal of Evolution of Medical and Dental Sciences - JEMDS 2019;8(20):166777.

[55] Nikita C, Verma H, Bhatnagar S, et al. Schwannoma of the larynx-a rare case report. Journal of Clinical and Diagnostic Research 2019;13(3):XD01-3.

[56] Urvashi C, Mayengbam S, Huidrom S, et al. Visa amongst MRSA isolates in a tertiary care hospital in Manipur. Journal of Evolution of Medical and Dental Sciences JEMDS 2017;6(77):5498-501.

[57] Sachin D, Prarthana P. To compare the changes in the corneal endothelium post phacoemulsification surgery with balanced salt solution vs. viscoelastic device. Journal of Clinical and Diagnostic Research 2019;13(12):1-4.

[58] Dangore-Khasbage S. Clinical aspects of oral cancer: a case report series. Dental and Medical Problems 2017;54(1):85-9.

[59] Dangore-Khasbage S, Bhowate R. Utility of the morphometry of the maxillary sinuses for gender determination by using computed tomography. Dental and Medical Problems 2018;55(4):411-7.

[60] Shravani D, Agarwal S, Chhabra KG, et al. Physical and psychological dependence of smokeless and smoked tobacco. Journal of Clinical and Diagnostic Research 2018;12(3):ZC01-4.

[61] Deolia S, Choudhary S, Vora S, et al. Evaluation of job satisfaction of Class III and Class IV workers in a tertiary medical care centre, Maharashtra. Journal of Evolution of Medical and Dental Sciences-Jemds 2019;8(51):3841-5.

[62] Gaikwad KB, Joshi NG, Selkar SP. Study of nitrosative stress in pregnancy induced hypertension. Journal of Clinical and Diagnostic Research 2017;11(3):BC06BC08.

[63] Gantasala BV, Singam A, Taksande K. Bupivacaine $(0.5 \%)$ versus $(0.5 \%)$ bupivacaine with ketamine $(50$ mg) for subarachnoid block in lower abdominal surgeries: a randomised comparative study. Journal of Clinical and Diagnostic Research 2019;13(3):UC16UC19.

[64] Gedam SR, Dhabarde A, Patil PS, et al. Psychiatric comorbidity, severity of dependence and liver enzymes dysfunction among alcohol dependent individuals: a cross-sectional study from central rural India. Journal of Clinical and Diagnostic Research 2019;13(4):VC01VC05.

[65] Ghoshal PK, Kamble RH, Shrivastav SS, et al. Radiographic evaluation of alveolar bone dimensions in the inter-radicular area between maxillary central incisors as "safe zone" for the placement of miniscrew implants in different growth patterns-a digital volume topographical study. Journal of Evolution of Medical and Dental Sciences - JEMDS 2019;8(51):3836-40. 
[66] Gomase PV, Dhamande MM, Kharpate S, et al. Impact of storage environment and temperature on dimensional stability of alginate impression. Journal of Evolution of Medical and Dental Sciences - JEMDS 2019;8(52):39946.

[67] Huidrom S, Chongtham U, Yumlembam B, et al. Prevalence and antibiotic susceptibility pattern of methicillin-resistant staphylococcus aureus (MRSA) isolates from different clinical specimens in a tertiary care hospital in Imphal. Journal of Evolution of Medical and Dental Sciences-JEMDS 2017;6(53):4039-41.

[68] Jagzape A, Jagzape T, Pathak S. Medical education terminologies: do these really percolate to the level of medical students? A survey. Journal of Clinical and Diagnostic Research 2017;11(9):JC01-JC05.

[69] Jajoo S, Shukla S, Acharya S. Presternal bronchogenic cyst: a rare presentation. Indian Journal of Medical Specialities 2019;10(2):105-7.

[70] John ZAS, Shrivastav S, Gurudatta NS, et al. An innovative approach to manage tooth size - arch length discrepancy. Journal of Evolution of Medical and Dental Sciences-JEMDS 2019;8(50):3819-21.

[71] Kamble AT, Kamble MK, Abhishek P. A comparative study on wound healing using placentrex, collagen, Vitamin C and Insulin. Journal of Evolution of Medical and Dental Sciences-JEMDS 2017;6(29):2366-71.

[72] Karam M, Singh YT, Singh MM. Management of small central perforation by tissue myringoplasty and conventional myringoplasty- a comparative study. Journal of Evolution of Medical and Dental SciencesJEMDS 2018;7(8):975-7.

[73] Kedia P, Bhushan M. Unilateral molluscum contagiosum following eyebrow grooming. Journal of Clinical and Diagnostic Research 2019;13(11):WD01WD02.

[74] Khan O, Irfan M, Lothe G, et al. Unusual presentation of focal tubercular meningoencephalitis in an elderly female. Journal of Evolution of Medical and Dental Sciences-JEMDS 2019;8(47):3560-2.

[75] Khandekar A, Dangre-Mudey G. Tackling rheumatic heart disease: prevalence and antibiogram of streptococcus pyogenes in cases of paediatric pharyngitis. Journal of Clinical and Diagnostic Research 2019;13(2).

[76] Khatib M, Khatib MN, Ahmed M, et al. Protocol on causal chain analysis and health economic modelling of childhood anaemia interventions in developing countries - a health technology assessment. Journal of Evolution of Medical and Dental Sciences-JEMDS 2019;8(51):3899-903.

[77] Kukde MM, Basak S, Selokar DS. Effect of heavy metal ions on Candida isolated from HIV positive patients. Journal of Clinical and Diagnostic Research 2019;13(4):ZC12-4.

[78] Kumar S, Agrawal S, Raisinghani N, et al. Leukocyte count: a reliable marker for the severity of organophosphate intoxication? Journal of Laboratory Physicians 2018;10(2):185-8.

[79] Kute PK, Muddeshwar MG, Sonare AR. Pro-Oxidant and anti-oxidant status in patients of psoriasis with relation to smoking and alcoholism. Journal of Evolution of Medical and Dental Sciences-JEMDS 2019;8(34):267780.

[80] Lakhkar BB, Damake S. Reducing complications of IV cannulation: a quality improvement project. Journal of Clinical and Diagnostic Research 2019;13(11):SH01SH02.
[81] Lamture YR, Salunke B. Anatomical variations related to position of appendix. Journal of Evolution of Medical and Dental Sciences - JEMDS 2018;7(46):5030-3.

[82] Lamture YR, Salunke B, Md. Shahabuddin. Carcinoma of breast- a study profile. Journal of Evolution of Medical and Dental Sciences - JEMDS 2018;7(45):4857-61.

[83] Marfani GM, Kashikar SV, Singhania S. Double barrel oesophagus - a case report. Journal of Clinical and Diagnostic Research 2018;12(8):TD01-TD02.

[84] Mittal V, Jagzape T, Sachdeva P. Care seeking behaviour of families for their sick infants and factors impeding to their early care seeking in rural part of central India. Journal of Clinical and Diagnostic Research 2018;12(4):SC08-SC12.

[85] Mundada G, Khan SM, Singhania SK, et al. Type-I monteggia with ipsilateral fracture of distal radius epiphyseal injury: a rare case report. Annals of African Medicine 2017;16(1):30-2.

[86] Nair RR, Mathew SS, Jose AM, et al. Reconstruction of scalp avulsion in a resource restraint rural hospital. Journal of Clinical and Diagnostic Research 2019;13(10):1-2.

[87] Palan A, Agrawal NK. Control of intraoperative shivering under spinal anaesthesia - a prospective randomized comparative study of butorphanol with tramadol. Journal of Krishna Institute of Medical Sciences University 2017;6(1):57-65.

[88] Papalkar PV, Sarode RR, Acharya S, et al. Cardiac manifestations in dengue. Indian Journal of Medical Specialities 2019;10(1):30-4.

[89] Pareek A, Khandekar A, Acharya S, et al. Correlation between nephropathy and ophthalmic complications in cases of sickle cell Anemia: an entangled association. Indian Journal of Medical Specialities 2019;10(2):72-5.

[90] Pfoze K, Rajshree H. Time of appearance of goblet cells in human small intestine. Journal of Evolution of Medical and Dental Sciences -JEMDS 2018;7(17):2099103.

[91] Prasad R, Khan M, Anjum F, et al. Tuberculosis of uterine cervix presenting with recurrent leucorrhoea in guise of carcinoma of cervix. Journal of Clinical and Diagnostic Research 2019;13(11):QD06-QD08.

[92] Priyanka AM, Jajoo SS. Risk of malignancy index in preoperative evaluation of adnexal masses. Journal of Evolution of Medical and Dental Sciences - JEMDS 2018;7(50):5352-7.

[93] Raina R, Kumar V, Krishna M, et al. A comparison of antibacterial efficacy of $0.5 \%$ sodium fluoride impregnated miswak and plain miswak sticks on streprococcus mutans - a randomized controlled trial. Journal of Clinical and Diagnostic Research 2017;11(2):ZC01-ZC04.

[94] Rajkumari R, Keithellakpam S, Thiyam J, et al. Relationship between psychosocial stress and menstrual function-related abnormalities among the female undergraduate medical students. Journal of Evolution of Medical and Dental Sciences - JEMDS 2017;6(38):3103-7.

[95] Rajkumari R, Keithellakpam S, Thiyam J, et al. A study on pain perception induced by cold pressor test among different $\mathrm{ABO}$ blood groups. Journal of Evolution of Medical and Dental Sciences - JEMDS 2019;8(29):23325.

[96] Ramteke S, Kambala S, Godbole S, et al. Comparative evaluation of the retentive qualities of three different post systems used for endodontically treated teeth for providing restoration - an in vitro study. Journal of Evolution of Medical and Dental Sciences - JEMDS 2019;8(50):3754-8. 
[97] Rathi A, Ransing RS, Mishra KK, et al. Quality of sleep among medical students: relationship with personality traits. Journal of Clinical and Diagnostic Research 2018;12(9):VC01-VC04.

[98] Salampuria S, Jajoo S, Acharya S. Acute respiratory distress syndrome during pregnancy and post-partum - a case series with spectrum of near miss to mortality. Journal of Evolution of Medical and Dental Sciences JEMDS 2019;8(49):3724-6.

[99] Samad SA, Phatak SV. An unusual case of abdominoscrotal swelling in a young patient-hydrocele en bissac. Journal of Clinical and Diagnostic Research 2018;12(11):TD03-TD05.

[100] Sathe S, Rathi D, Borle A. Full mouth rehabilitation of severely worn dentition by an interdisciplinary approach. Journal of Evolution of Medical and Dental Sciences - JEMDS 2019;8(49):3727-9.

[101] Schwartz GG, Steg PG, Szarek M, et al. Alirocumab and cardiovascular outcomes after acute coronary syndrome. New England Journal of Medicine 2018;379(22):2097-107.

[102] Shaheed R, Shukla S, Acharya S, et al. Journey from fighters to survivors: quality of life and mental status in cancer patients in a rural tertiary care hospital. Journal of Clinical and Diagnostic Research 2019;13(8):XC01XC04.

[103] Shivakumar KM, Kadashetti V, Chaudhary M, et al. Prevalence of oral mucosal lesions in patients with dermatological diseases attending tertiary care hospital in central India. Journal of Krishna Institute of Medical Sciences University 2017;6(3):55-61.

[104] Singam AP, Chaudhary A, Shrey S. Anatomical landmark guided versus ultrasound-guided technique for subclavian vein cannulation in critically ill patients. Journal of Krishna Institute of Medical Sciences University 2019;8(4):50-7.

[105] Singh H, Agrawal M, Bhake A, et al. Colour Doppler evaluation in high-risk pregnancy and perinatal outcome. Journal of Evolution of Medical and Dental Sciences - JEMDS 2018;7(43):4603-8.

[106] Singh KI, Javan NG, Meitei SK. Posterior urethral valvesour experience. Journal of Evolution of Medical and Dental Sciences - JEMDS 2017;6(27):2258-63.

[107] Singh OH, Singh NS, Sarkar R, et al. Association between gall bladder diameter and calculus in the cystic duct in gall stone diseases and its importance in the current surgical practice- a cross-sectional study in Jnims, Porompat, Manipur. Journal of Evolution of Medical and Dental Sciences-JEMDS 2018;7(7):856-9.

[108] Singh R, Singam A. Comparative evaluation of dexmedetomedine versus clonidine as an adjuvant in supraclavicular brachial plexus block. Journal of Krishna Institute of Medical Sciences University 2019;8(3):53-65.

[109] Singh SS, Javan NG, Singh KI, et al. Early laparoscopic appendicectomy in management of appendiceal mass. Journal of Evolution of Medical and Dental Sciences JEMDS 2017;6(59):4367-71.

[110] Somani R, Panda P, Dungarwal M, et al. Idiopathic Charcot's arthropathy of ankle joint: a rare case. Journal of Clinical and Diagnostic Research 2019;13(3):RD03RD05.

[111] Srivastava TK, Mishra V, Waghmare LS. Formative assessment classroom techniques (FACTS) for better learning in pre-clinical medical education: a controlled trial. Journal of Clinical and Diagnostic Research 2018;12(9):JC01-JC08.

[112] Swarnkar K, Gaikwad S, Uke P, et al. Apert syndrome presenting with omphalocele. Journal of Krishna
Institute of Medical Sciences University 2019;8(1):959.

[113] Swarnkar M. Giant calcifying aponeurotic fibroma of web space: case report with review of literature. Journal of Krishna Institute of Medical Sciences University 2019;8(2):99-102.

[114] Swarnkar M, Jain SC. Heterotopic subserosal pancreatic tissue in jejunum-an incidental rare finding. Journal of Krishna Institute of Medical Sciences University 2017;6(4):105-8.

[115] Swarnkar M, Jindal R. Obstructed obturator hernia: a diagnostic dilemma. Journal of Krishna Institute of Medical Sciences University 2019;8(3):115-7.

[116] Tekade SA, Chaudhary MS, Tekade SS, et al. Early stage oral submucous fibrosis is characterized by increased vascularity as opposed to advanced stages. Journal of Clinical and Diagnostic Research 2017;11(5):ZC92ZC6.

[117] Tendulkar MP, Ninave SS. Prospective comparison of pressor and airway responses to IV esmolol and IV dexmedetomidine during emergence from general anaesthesia and extubation. Journal of Krishna Institute of Medical Sciences University 2017;6(1):49-56.

[118] Verghese B, Acharya S, Khandekar A, et al. Clinical profile of patients of sickle cell crisis in a rural tertiary care hospital. Journal of Evolution of Medical and Dental Sciences - JEMDS 2019;8(42):3114-8.

[119] Wasnik RR, Akarte NR. Evaluation of serum zinc and antioxidant vitamins in adolescent homozygous sickle cell patients in Wardha, District of Central India. Journal of Clinical and Diagnostic Research 2017;11(8):BC01-BC03.

[120] Yarappa R, Gagneja S, Acharya S, et al. Lemierre's syndrome: a calamitous complication of oropharyngeal infection. Journal of Head \& Neck Physicians and Surgeons 2019;7(2):82-4.

[121] Yeola ME, Borgaonkar AP. Passage of gangrenous small bowel per rectum following superior mesenteric vessel thrombosis. Journal of Clinical and Diagnostic Research 2019;13(12):PD03-PD04.

[122] Kumar S, Bhayani P, Hathi D, et al. Hyponatremia initial presenting feature of normal pressure hydrocephalus in elderly patient: a rare case report. Journal of Gerontology and Geriatrics 2018;66(3):156-7.

[123] Papalkar P, Kumar S, Agrawal S, et al. Heterotaxy syndrome presenting as severe pulmonary artery hypertension in a young old female: case report. Journal of Gerontology and Geriatrics 2018;66(2):5961.

[124] Agrawal A, Kumar S, Bhagwati J. Correlation of platelet indices with clinical profile in elderly patients: a study in rural teaching hospital. Annals of Medical and Health Sciences Research 2018;8(3):163-9.

[125] Gondivkar SM, Bhowate RR, Gadbail AR, et al. Comparison of generic and condition-specific oral health-related quality of life instruments in patients with oral submucous fibrosis. Quality of Life Research 2019;28(8):2281-8.

[126] Lahoti S, Kumar S, Agrawal S. Study of carotid intimal medial thickness in chronic kidney disease at rural teaching hospital. Annals of Medical and Health Sciences Research 2017;7(1):76-80.

[127] Zodpey S, Sharma A, Zahiruddin QS, et al. Allopathic doctors in India: estimates, norms and projections. Journal of Health Management 2018;20(2):151-63.

[128] Garg S, Chakravarti A, Singh R, et al. Dengue. INTE serotype-specific seroprevalence among 5-to 10-yearold children in India: a community-based cross- 
sectional study. National Journal of Infectious Diseases 2017;54:25-30.

[129] Sharma SK, Chaubey J, Singh BK, et al. Drug resistance patterns among extra-pulmonary tuberculosis cases in a tertiary care centre in north India. International Journal of Tuberculosis and Lung Disease 2017;21(10):1112-7.

[130] Kadu AS, Rajput DS, and Deshmukh SG. Management of recurrent nasal vestibular furunculosis by Jalaukavacarana and palliative treatment. Ancient Science of Life 2017;36(4):220-4.

[131] Kuchewar V. A case study on successful ayurvedic management of a rare case of Reiter's Syndrome. Ancient Science of Life 2017;36(4):225-8.

[132] Taksande A, Meshram R, Yadav $P$, et al. Rare presentation of cerebral venous sinus thrombosis in a child. Journal of Pediatric Neurosciences 2017;12(4):389-92.

[133] Bagri-Manjrekar K, Chaudhary M, Sridharan G, et al. In vivo autofluorescence of oral squamous cell carcinoma correlated to cell proliferation rate. Journal of Cancer Research and Therapeutics 2018;14(3):553-8.

[134] Gondivkar SM, Bhowate RR, Gadbail AR, et al. Impact of socioeconomic inequalities on quality of life in oral submucous fibrosis patients. Future Oncology 2019;15(8):875-83.

[135] Mathur A, Rastogi N, Gurjar D, et al. Safety and efficacy of weekly versus three-weekly paclitaxel plus platinum neoadjuvant chemotherapy in patients with locally advanced squamous cell head and neck carcinoma: a pilot study. South Asian Journal of Cancer 2018;7(4):254-7.

[136] Patil NN, Wadhwan V, Nayyar AS, et al. KAI-1 Ad P53 expression in odontogenic cysts: an immunohistochemical marker study. Clinical Cancer Investigation Journal 2018;7(2):62-9.

[137] Jain S, Gaurkar S, Deshmukh PT, et al. Applied anatomy of round window and adjacent structures of tympanum related to cochlear implantation. Brazilian Journal of Otorhinolaryngology 2019;85(4):435-46.

[138] Gadbail AR, Chaudhary M, Gawande M, et al. Oral squamous cell carcinoma in the background of oral submucous fibrosis is a distinct clinicopathological entity with better prognosis. Journal of Oral Pathology \& Medicine 2017;46(6):448-53.

[139] Gadbail AR, Chaudhary MS, Sarode SC, et al. Ki67, CD105 and Alpha-SMA expressions better relate the binary oral epithelial dysplasia grading system of World Health Organization. Journal of Oral Pathology \& Medicine 2017;46(10):921-7.

[140] Gupta V, Bhake A. Assessment of clinically suspected tubercular lymphadenopathy by real-time PCR compared to non-molecular methods on lymph node aspirates. Acta Cytologica 2018;62(1):4-11.

[141] Gupta V, Bhake A. Molecular diagnosis of tubercular lymphadenopathy from fine-needle aspirates in pediatric patients. Acta Cytologica 2017;61(3):173-8.

[142] Gupta V, Bhake A. Reactive lymphoid hyperplasia or tubercular lymphadenitis: can real-time PCR on fineneedle aspirates help physicians in concluding the diagnosis? Acta Cytologica 2018;62(3):204-8.

[143] Jain J, Banait S, Tiewsoh I, et al. Kikuchi's disease (histiocytic necrotizing lymphadenitis): a rare presentation with acute kidney injury, peripheral neuropathy and aseptic meningitis with cutaneous involvement. Indian Journal of Pathology and Microbiology 2018;61(1):113-5.
[144] Sarode SC, Chaudhary M, Gadbail A, et al. Dysplastic features relevant to malignant transformation in atrophic epithelium of oral submucous fibrosis: a preliminary study. Journal of Oral Pathology \& Medicine 2018;47(4):410-6.

[145] Girish M, Rawekar A, Jose S, et al. Utility of low fidelity manikins for learning high quality chest compressions. Indian Journal of Pediatrics 2018;85(3):184-8.

[146] Kurhade KA, Purandare S. Twenty-four hours' transcutaneous bilirubin as a predictor of subsequent 3rd day neonatal hyperbilirubinemia. Journal of Clinical Neonatology 2017;6(1):6-9.

[147] Taksande A, Meshram R, Lohakare A. A rare presentation of isolated oculomotor nerve palsy due to multiple sclerosis in a child. International Journal of Pediatrics 2017;5(8):5525-9.

[148] Taksande A, Meshram R, Yadav P, et al. A rare case of Budd Chiari syndrome in a child. International Journal of Pediatrics 2017;5(10):5809-12.

[149] Gupta R, Das S, Gujar K, et al. Clinical practice guidelines for sleep disorders. Indian Journal of Psychiatry 2017;59(Suppl 1):S116-S38.

[150] Pal S, Oswal RM, Vankar GK. Recognition of major depressive disorder and its correlates among adult male patients in primary care. Archives of Psychiatry and Psychotherapy 2018;3:55-62.

[151] Patel A, Barot CK, Vankar G, et al. Acting on delusions in patients suffering from schizophrenia. Archives of Psychiatry and Psychotherapy 2019;21(4):52-61.

[152] Patel TV, Brahmbhatt MJ, Vankar GK. Prevalence of alcohol use disorders in hospitalised male patients. Archives of Psychiatry and Psychotherapy 2018;4:4755.

[153] Tripathi A, Avasthi A, Grover S, et al. Gender differences in obsessive-compulsive disorder: findings from a multicentric study from India. Asian Journal of Psychiatry 2018;37:3-9.

[154] Aryal N, Regmi PR, Faller EM, et al. Sudden cardiac death and kidney health related problems among Nepali migrant workers in Malaysia. Nepal Journal of Epidemiology 2019;9(3):788-91.

[155] Dhar R, Singh S, Talwar D, et al. Bronchiectasis in India: results from the European Multicentre Bronchiectasis Audit and Research Collaboration (EMBARC) and Respiratory Research Network of India Registry. Lancet Global Health 2019;7(9):e1269-e79.

[156] Gondivkar SM, Bhowate RR, Gadbail AR, et al Comparison of generic and condition-specific oral health-related quality of life instruments in patients with oral submucous fibrosis. Quality of Life Research 2019;28(8):2281-8.

[157] Khanam N, Wagh V, Gaidhane AM, et al. Assessment of work-related musculoskeletal morbidity, perceived causes and preventive activities practiced to reduce morbidity among brick field workers. Indian Journal of Community Health 2019;31(2):213-9.

[158] Puri S, Fernandez S, Puranik A, et al. Policy content and stakeholder network analysis for infant and young child feeding in India. BMC Public Health 2017;17(2):461.

[159] Regmi PR, van Teijlingen E, Mahato P, et al. The health of Nepali migrants in India: a qualitative study of lifestyles and risks. International Journal of Environmental Research and Public Health 2019;16(19):3655.

[160] Thow AM, Karn S, Devkota MD, et al. Opportunities for strengthening infant and young child feeding policies in 
south Asia: insights from the SAIFRN policy analysis project. BMC Public Health 2017;17(Suppl 2):404.

[161] Uddin S, Mahmood H, Senarath U, et al. Analysis of stakeholders networks of infant and young child nutrition programmes in Sri Lanka, India, Nepal, Bangladesh and Pakistan. BMC Public Health 2017;17(Suppl 2):405.

[162] Sharma S, Singh AD, Sharma SK, et al. Gallium-68 DOTANOC PET/CT as an alternate predictor of disease activity in Sarcoidosis. Nuclear Medicine Communications 2018;39(8):768-78.

[163] Chandankar SB, Kuchewar V. Management of Vipadika through Ayurveda. International Journal of Ayurvedic Medicine 2019;10(1):122-4.

[164] Deogade MS, Desai P, Prasad KSR. Efficacy of small group teaching and its comparison with classroom teaching in the subject of Dravyaguna. International Journal of Ayurvedic Medicine 2017;8(3):115-8.

[165] Deogade MS, Prasad KSR. Standardization of wild Krushnatulasi (Ocimum Tenuiflorum Linn) leaf. International Journal of Ayurvedic Medicine 2019;10(1):52-61.

[166] Deshmukh S, Jibkate B, Zanwar A. Therapeutic emesis (Vamana) - management of Ekakustha - a case study. International Journal of Ayurvedic Medicine 2017;8(1):30-4.

[167] Gawande P, Nayak S, Mudey A, et al. Assessment of risk factor of NCD in Nachangaon village at Wardha District'. International Journal of Medical Research \& Health Sciences 2017;6(4):75-9.

[168] Gupta RK, Deogade MS. Antioxidant activities of Martynia annua Linn. Root extract. International Journal of Ayurvedic Medicine 2019;10(4):326-8.

[169] Hagone PA, Kuchewar V. Management of glomerulonephritis through Ayurveda - a case report. International Journal of Ayurvedic Medicine 2019;10(4):345-7.

[170] Kogade P, Gaidhane A, Choudhari S, et al. Socio-cultural determinants of infant and young child feeding practices in rural India. Medical Science 2019;23(100):1015-22.

[171] Kombe P, Kuchewar V. Evaluation of effect of Kanchanar Guggul in sub-clinical hypothyroidism with respect to Agnimandya. International Journal of Ayurvedic Medicine 2019;10(4):310-6.

[172] Sawarkar P, Sawarkar G. Peer-assisted learning of procedural skill in Basti Karma (medicated enema) a pilot study. International Journal of Ayurvedic Medicine 2019;10(4)317-22.

[173] Talwar D, Kumar S, Andhale A, et al. Chilaiditi syndrome, unusual complication of rather innocuous abnormality: case report. Medical Science 2019;23(100):1011-4.

[174] Wajpeyi SM. Role of Ayurveda in the management of Guillain-Barre syndrome case study. International Journal of Ayurvedic Medicine 2018;9(4):288-92.

[175] Zanwar AC, Wajpeyi SM. Management of Hepatitis B (carrier stage) through Ayurved - a case report. International Journal of Ayurvedic Medicine 2019;10(4):342-4.
[176] Sharma SK, Chaubey J, Singh BK, et al. Drug resistance patterns among extra-pulmonary tuberculosis cases in a tertiary care centre in North India. International Journal of Tuberculosis and Lung Disease 2017;21(10):1112-7.

[177] Jain S, Singh P, Methwani D, et al. Role of eustachian dysfunction and primary sclerotic mastoid pneumatisation pattern in aetiology of squamous chronic otitis media: a correlative study. Indian Journal of Otolaryngology and Head \& Neck Surgery 2019;71(Suppl 2):1190-6.

[178] Mahalle S. Osteoma of external auditory canal associated with external auditory canal cholesteatoma and exuberant granulation tissue in mastoid air cell system: a rare association. Indian Journal of Otolaryngology and Head \& Neck Surgery 2019;71(Suppl 2):1505-7.

[179] Swarnkar M, Agrawal A. Kimura's disease. Formosan Journal of Surgery 2018;51(1):26-8.

[180] Swarnkar M, Pandey P. Heterotopic subserosal pancreatic tissue in Jejunum. Formosan Journal of Surgery 2018;51(4):167-70.

[181] Balwani M, Bawankule C, Ramteke V, et al. Hepatitis C Virus, directly acting antivirals and Guillain-Barre syndrome. Saudi Journal of Kidney Diseases and 2018;29(5):1237-9.

[182] Balwani MR, Bawankule C, Khetan P, et al. An uncommon cause of rapidly progressive renal failure in a lupus patient: Pauci-immune crescentic glomerulonephritis. Saudi Journal of Kidney Diseases and Transplantation 2018;29(4):989-92.

[183] Balwani MR, Bawankule CP, Khetan P, et al. Awareness about kidney and its related function/dysfunction in school going children: a survey from the Central India. Saudi Journal of Kidney Diseases and Transplantation 2019;30(1):202-7.

[184] Balwani MR, Bawankule CR, Pasari A, et al. Minimal change disease and Kimura's disease responding to Tacrolimus therapy. Saudi Journal of Kidney Diseases and Transplantation 2019;30(1):254-7.

[185] Balwani MR, Pasari A, Meshram A, et al. An initial evaluation of hypokalemia turned out distal renal tubular acidosis secondary to parathyroid adenoma. Saudi Journal of Kidney Diseases and Transplantation 2018;29(5):1216-9.

[186] Balwani MR, Pasari A, Tolani P. Widening spectrum of renal involvement in psoriasis: first reported case of $c 3$ glomerulonephritis in a psoriatic patient. Saudi Journal of Kidney Diseases and Transplantation 2019;30(1):258-60.

[187] Goswami J, Balwani MR, Kute V, et al. Scoring systems and outcome of chronic kidney disease patients admitted in Intensive Care Units. Saudi Journal of Kidney Diseases and Transplantation 2018;29(2):3107.

[188] Varyani UT, Shah NM, Shah PR, et al. C1q nephropathy in a patient of neurofibromatosis type 1: a rare case report. Indian Journal of Nephrology 2019;29(2):125 7. 